\title{
Grids for Applications in High-Temperature High-Resolution Transmission Electron Microscopy
}

\author{
Yucheng Lan, ${ }^{1}$ Hui Wang, ${ }^{1}$ Dezhi Wang, ${ }^{1}$ Gang Chen,, ${ }^{2}$ and Zhifeng Ren ${ }^{1}$ \\ ${ }^{1}$ Department of Physics, Boston College, Chestnut Hill, MA 02467, USA \\ ${ }^{2}$ Department of Mechanical Engineering, Massachusetts Institute of Technology, Cambridge, MA 02139, USA \\ Correspondence should be addressed to Zhifeng Ren, zhifeng.ren@bc.edu
}

Received 3 March 2010; Revised 25 May 2010; Accepted 17 June 2010

Academic Editor: Thomas Thundat

Copyright ( $) 2010$ Yucheng Lan et al. This is an open access article distributed under the Creative Commons Attribution License, which permits unrestricted use, distribution, and reproduction in any medium, provided the original work is properly cited.

\begin{abstract}
New TEM grids coated with ultrathin amorphous $\mathrm{Al}_{2} \mathrm{O}_{3}$ films have been developed using atomic layer deposition technique. The amorphous $\mathrm{Al}_{2} \mathrm{O}_{3}$ films can withstand temperatures over $600^{\circ} \mathrm{C}$ in air and $900^{\circ} \mathrm{C}$ in vacuum when the thickness of the $\mathrm{Al}_{2} \mathrm{O}_{3}$ film is $2 \mathrm{~nm}$, and up to $1000^{\circ} \mathrm{C}$ in air when the thickness is $25 \mathrm{~nm}$, which makes heating TEM grids with nanoparticles up to $1000^{\circ} \mathrm{C}$ in air and immediate TEM observation without interrupting the nanoparticles possible. Such coated TEM grids are very much desired for applications in high-temperature high-resolution transmission electron microscopy.
\end{abstract}

\section{Introduction}

High-temperature high-resolution transmission electron microscopy (HRTEM) has been widely utilized to study the dynamic behaviors of nanoparticles at elevated temperatures [1-11], such as morphology [1], oxidation [2], melting [3-5], structural transformation [6], evaporation [7], recrystallization [8], phase stability [9], and growth [10] of nanoparticles. In these high-temperature HRTEM investigations, the supporting films coated on TEM grids should be thin enough (not to blur the HRTEM images of nanoparticles) and be mechanically stable (to support the nanoparticles) up to several hundred Celsius right before TEM observation without postheating processing.

Unfortunately such ideal ultra-thin and mechanically stable supporting films are not available. The conventional ultra-thin carbon supporting films with thickness of several nanometers are suitable for HRTEM imaging and electron diffraction patterning at room temperature and in vacuum [12]. However, the carbon supporting films are not mechanically stable at high temperatures, always break in vacuum or burn away in air upon heating. In order to improve mechanical stability of the carbon supporting films, a thermally stable silicon oxide was deposited on the conventional carbon films using sputtering method [13]. The deposited oxide films were too thick and blurred HRTEM images while the quality of the deposited oxide films was hard to be controlled because of the sputtering deposition technique. Gold-platinum alloys [14] and germanium films [15] were also sputtered on the carbon supporting films, but the coated films were only suitable for HRTEM up to $500^{\circ} \mathrm{C}$ in vacuum and could not resist oxidization in air at high temperatures. In order to withstand temperatures higher than $500^{\circ} \mathrm{C}$, silicon-based membrane window grids, like silicon oxide membranes [16] and silicon nitride membranes[17], have recently been developed to meet the new requirement of high-temperature TEM experiments. These commercial membrane window grids can withstand temperatures up to $1000^{\circ} \mathrm{C}$ in air and the thickness of these membranes is usually several ten nanometers. The quality of obtained HRTEM images from these membranes is better than those from the sputtering films while is worse than those from the ultra-thin carbon films.

Atomic layer deposition (ALD) can deposit very uniform thin films on various substrates based on a sequential use of a gas-phase chemical process [18]. Large-area, ultra-thin, and uniform films can be produced with precise control of the thickness and composition at atomic level. The thickness of the ALD films can be precisely controlled from several Ångströns to several hundred nanometers.

Here, we successfully utilized the ALD technique to fabricate $\mathrm{Al}_{2} \mathrm{O}_{3}$ TEM-supporting films with thickness varying 


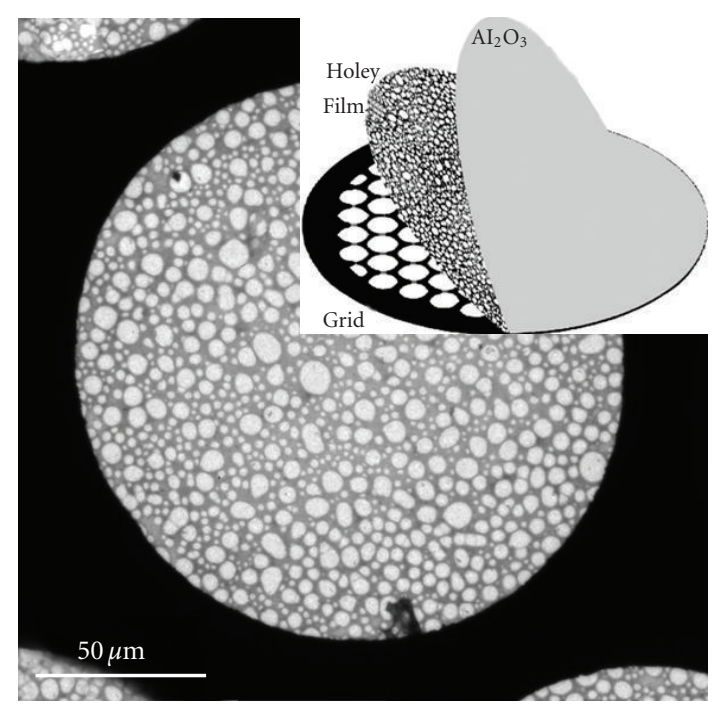

(a)

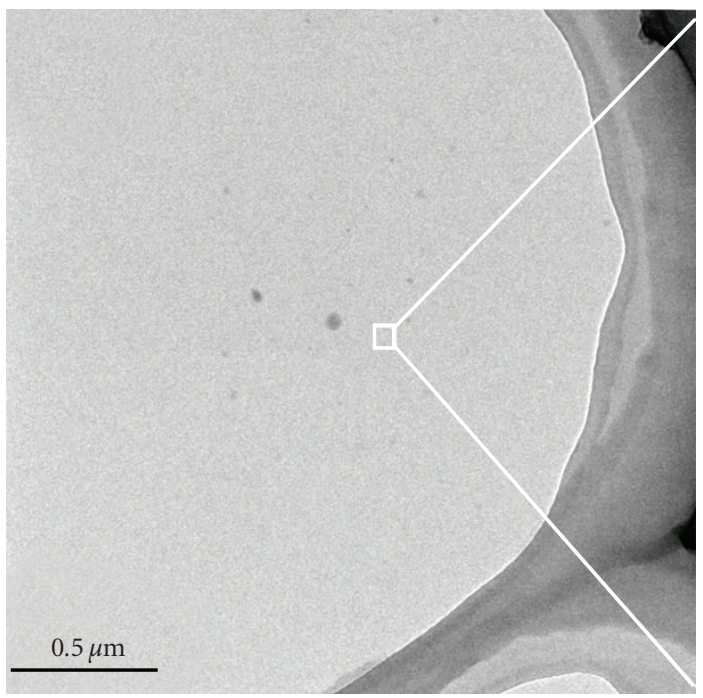

(c)

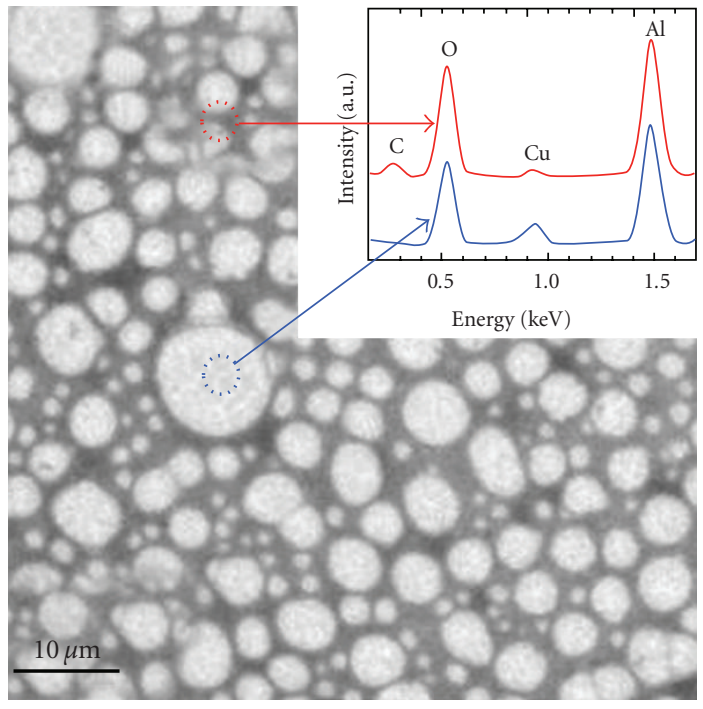

(b)

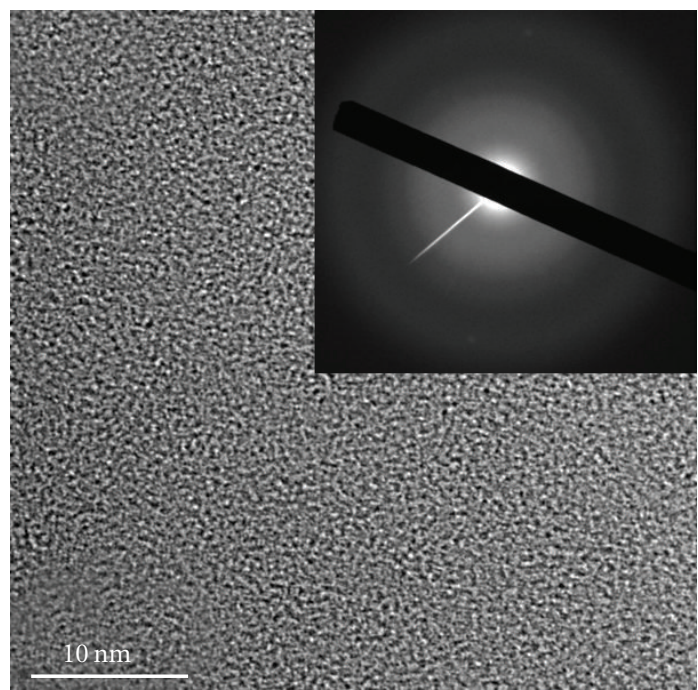

(d)

Figure 1: TEM images of ALD $\mathrm{Al}_{2} \mathrm{O}_{3}$ films with thickness of $2 \mathrm{~nm}$ at (a) low magnification, (b) medium magnification, (c) high magnification, and (d) HRTEM. Inset in (a) illustrates the layer-structure of a coated TEM grid with part of the $\mathrm{Al}_{2} \mathrm{O}_{3}$ film and holey carbon film raised for viewing purpose. Inset in (b) is EDS of the ALD film. The top spectrum comes from the holey carbon region while the bottom one from the thin $\mathrm{Al}_{2} \mathrm{O}_{3}$ film region. Inset in (d) is SAED of the $\mathrm{Al}_{2} \mathrm{O}_{3}$ film.

from $2 \mathrm{~nm}$ to $25 \mathrm{~nm}$. Such new TEM grids coated with amorphous $\mathrm{Al}_{2} \mathrm{O}_{3}$ films are mechanically stable over $600^{\circ} \mathrm{C}$ in air when the thickness of ALD films is $2 \mathrm{~nm}$ and stable up to $1000^{\circ} \mathrm{C}$ in air when the thickness is $25 \mathrm{~nm}$, and even higher in vacuum, suitable for high-temperature HRTEM investigations.

\section{Experimental}

Commercial holey carbon TEM grids coated with a continuous ultra-thin carbon film were loaded into an ALD chamber (Savanna 100, Cambridge NanoTech Inc.), pumped down to $1 \times 10^{-3} \mathrm{~Pa}$ and heated to $120^{\circ} \mathrm{C}$. Then, $\mathrm{Al}_{2} \mathrm{O}_{3}$ amorphous films were deposited on the carbon-coated TEM grids, using water and trimethylaluminum (TMA) as the sources for oxygen and aluminum, respectively. The ALD process was performed by alternatively supplying pulses of nitrogen gas containing water and TMA with each cycle consisting of a 15milliseconds water pulse, a 5-second nitrogen purge period, a 15-millisecond TMA pulse, and a 5-second nitrogen purge period. The deposition rate of $\mathrm{Al}_{2} \mathrm{O}_{3}$ was $0.10 \mathrm{~nm}$ per cycle. The thickness of the amorphous $\mathrm{Al}_{2} \mathrm{O}_{3}$ films was controlled by the cycle number. After deposition, the TEM grids were cooled down to $100^{\circ} \mathrm{C}$, taken out from the ALD chamber, plasma cleaned, and heated in air at $300^{\circ} \mathrm{C}$ to burn the continuous ultra-thin carbon film over the holes of the holey carbon film that were exposed to air. 


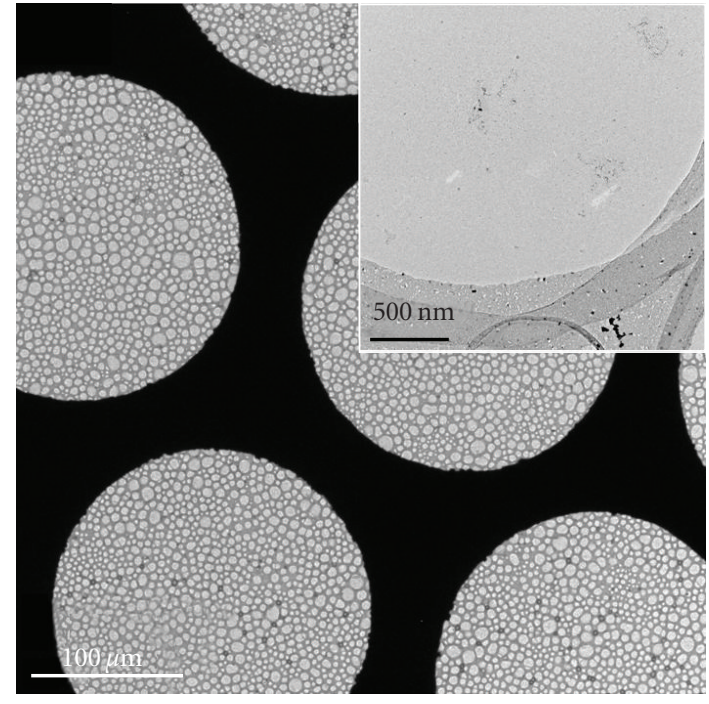

(a)

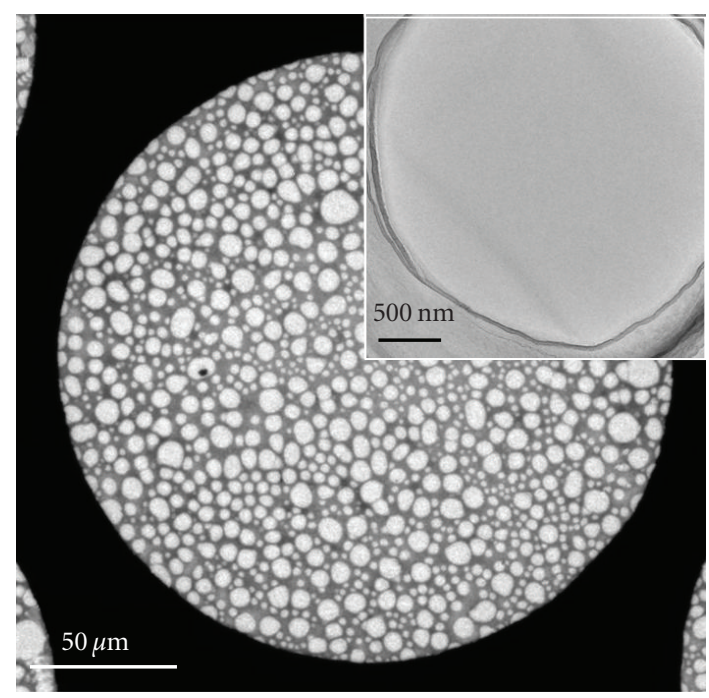

(c)

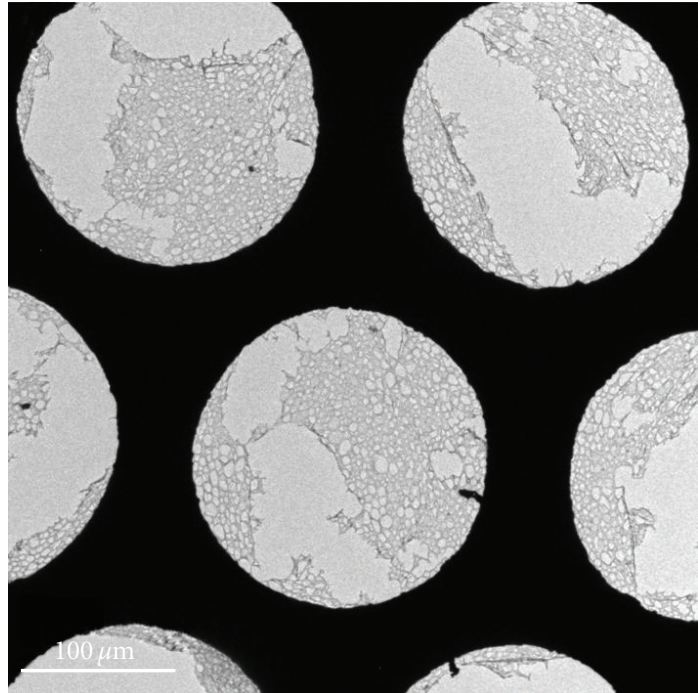

(b)

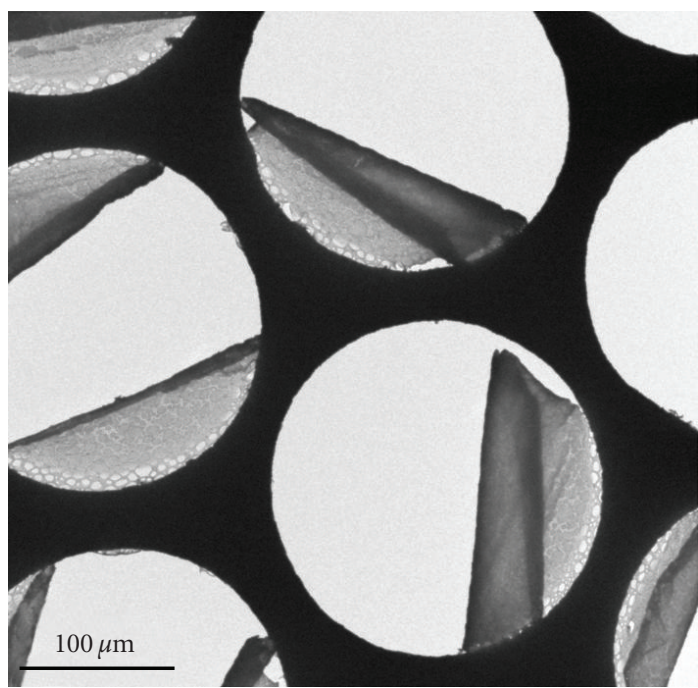

(d)

FIgure 2: Low magnification TEM images of $\mathrm{ALD}-\mathrm{Al}_{2} \mathrm{O}_{3}$ films with $2 \mathrm{~nm}$ thickness heated at (a) $600^{\circ} \mathrm{C}$ in air, (b) $700^{\circ} \mathrm{C}$ in air, (c) $900^{\circ} \mathrm{C}$ in vacuum, and (d) $985^{\circ} \mathrm{C}$ in vacuum. The insets in (a) and (c) are enlarged TEM images of the $\mathrm{Al}_{2} \mathrm{O}_{3}$ film over a hole of holey carbon film.

In order to test the mechanical stability of the amorphous $\mathrm{Al}_{2} \mathrm{O}_{3}$ films, the ALD-coated TEM grids were heated in a tube furnace in air at different temperatures up to $1000^{\circ} \mathrm{C}$, or heated in vacuum $\left(10^{-5} \mathrm{~Pa}\right)$ in TEM column using a Gatan double tilt heating holder (Model 652, Gatan Inc.) at different temperatures up to $1200^{\circ} \mathrm{C}$. Microstructures of the amorphous ALD $\mathrm{Al}_{2} \mathrm{O}_{3}$ films were characterized on a JEOL-2010F TEM equipped with an Oxford energy dispersive X-ray spectrometer, operated at an accelerating voltage of $200 \mathrm{kV}$.

\section{Results and Discussion}

Figure 1 is a plan-view of an ALD-coated TEM grid with an amorphous $\mathrm{Al}_{2} \mathrm{O}_{3}$ film deposited with 20 cycles. Inset in Figure 1(a) illustrates the layer structure of the ALD-coated TEM grids consisting of a continuous $\mathrm{Al}_{2} \mathrm{O}_{3}$ film (partly raised for viewing purpose), a holey carbon film (partly raised for viewing purpose), and a TEM grid. The thickness of the $\mathrm{Al}_{2} \mathrm{O}_{3}$ film is about $2.0 \mathrm{~nm}$. The ALD $\mathrm{Al}_{2} \mathrm{O}_{3}$ film is continuous and covers the whole TEM grid of $3.05 \mathrm{~mm}$ diameter (Figures 1(a)-1(c)). Energy-dispersive X-ray spectroscopy (EDS) indicates that the ALD film over a hole of the holey carbon film consists of oxygen and aluminum without carbon within the experimental errors (bottom curve in inset of Figure 1(b)). EDS also indicates that the holey carbon film is still there (top curve in inset of Figure 1(b)). The holey carbon film supports the $\mathrm{ALD}-\mathrm{Al}_{2} \mathrm{O}_{3}$ film. The ratio of aluminum and oxygen is calculated from EDS, $\mathrm{Al}: \mathrm{O}=$ $2.0: 3.2$, close to the element ratio of $\mathrm{Al}_{2} \mathrm{O}_{3}$. The slightly high oxygen content may come from the oxygen absorbed on the ALD film surfaces. The ratio of aluminum and oxygen is spatially uniform on the whole ALD film. 


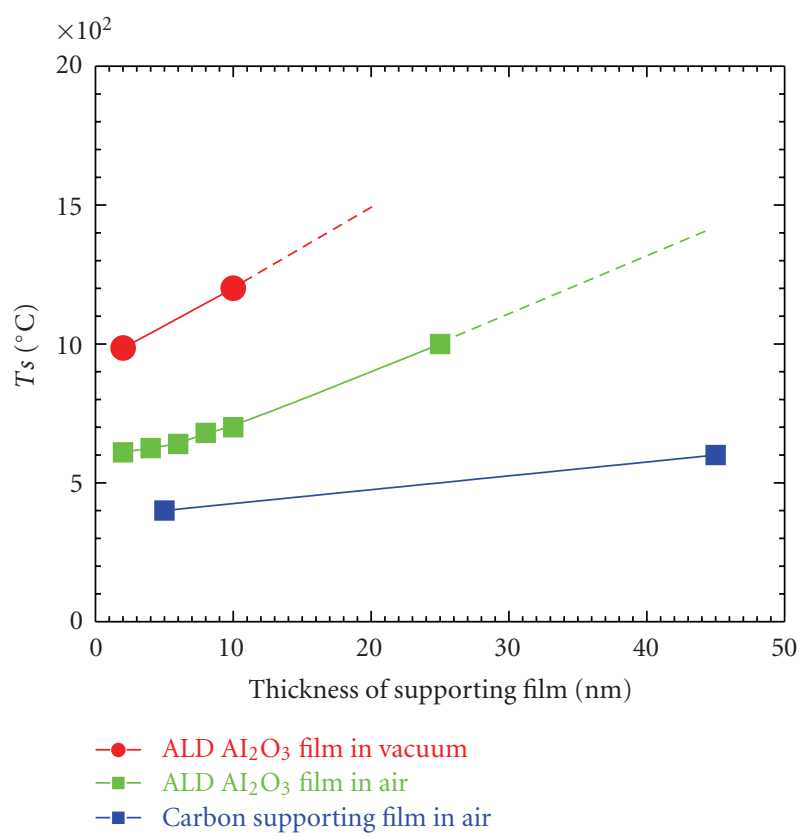

Figure 3: Mechanical stability dependence of thickness of ALD $\mathrm{Al}_{2} \mathrm{O}_{3}$ films with data of carbon supporting films for comparison.

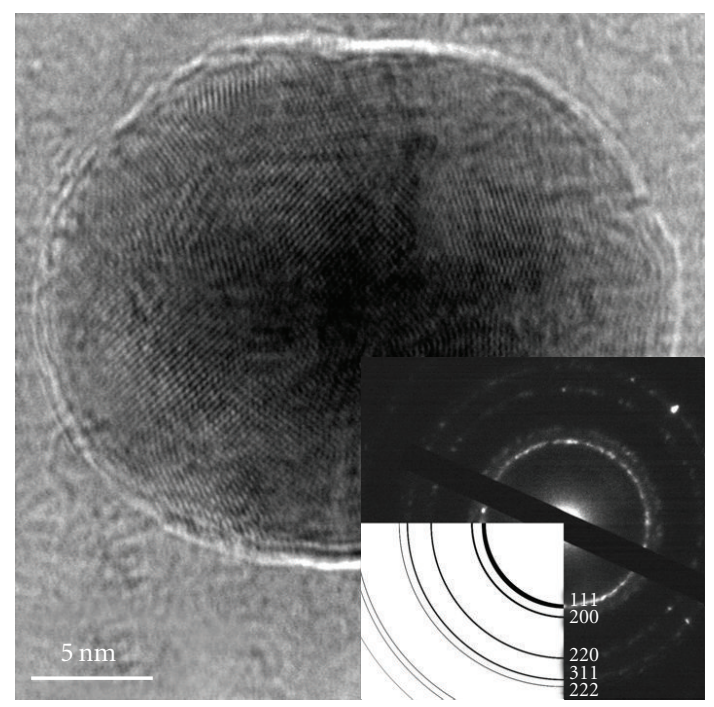

FIgURe 4: In situ HRTEM image of a silver nanoparticle taken at $500^{\circ} \mathrm{C}$ in vacuum. Inset: In situ SAED pattern of the nanoparticle taken at $500^{\circ} \mathrm{C}$.

HRTEM and selected area electron diffraction (SAED) (Figure $1(\mathrm{~d})$ ) indicate that the $\mathrm{ALD} \mathrm{Al}_{2} \mathrm{O}_{3}$ film is amorphous. HRTEM of the ALD film does not show any thickness contrast, indicating the thickness of the $\mathrm{Al}_{2} \mathrm{O}_{3}$ film is uniform at nanoscale. Atomic force microscopy indicated that such grown $\mathrm{ALD} \mathrm{Al}_{2} \mathrm{O}_{3}$ thin films are smooth at atomic level with a root-mean-squared roughness of several Ångströns [18, 19].

The ultra-thin ALD $\mathrm{Al}_{2} \mathrm{O}_{3}$ films are mechanically stable at high temperature in air and in vacuum. Figure 2 is a plan view of the amorphous $\mathrm{ALD} \mathrm{Al}_{2} \mathrm{O}_{3}$ films after being heated at various temperatures. The amorphous $\mathrm{Al}_{2} \mathrm{O}_{3}$ film is still continuous after being heated at $600^{\circ} \mathrm{C}$ for 5 minutes in air (Figure 2(a)). SAED indicates that the ALD film is still amorphous after being heated. After being heated at $700^{\circ} \mathrm{C}$ for 5 minutes in air, big voids are formed in the ALD film, and the $\mathrm{ALD} \mathrm{Al}_{2} \mathrm{O}_{3}$ film is broken (Figure 2(b)).

The ALD $\mathrm{Al}_{2} \mathrm{O}_{3}$ film is more mechanically stable in vacuum $\left(<1 \times 10^{-5} \mathrm{~Pa}\right)$ than in air. After being heated at $900^{\circ} \mathrm{C}$ for over 10 minutes in vacuum, the morphology of the ALD $\mathrm{Al}_{2} \mathrm{O}_{3}$ film is same as before being heated (Figure 2(c)). The heated ALD $\mathrm{Al}_{2} \mathrm{O}_{3}$ film is still amorphous. After being heated at $985^{\circ} \mathrm{C}$ for 10 minutes in vacuum, the ALD $\mathrm{Al}_{2} \mathrm{O}_{3}$ film breaks and rolls up (Figure 2(d)).

Crystallization of amorphous $\mathrm{ALD} \mathrm{Al}_{2} \mathrm{O}_{3}$ films on silicon wafers was investigated in air by X-ray diffraction [20-22]. It was found that amorphous $\mathrm{ALD} \mathrm{Al}_{2} \mathrm{O}_{3}$ films crystallize into $\gamma-\mathrm{Al}_{2} \mathrm{O}_{3}$ at $900^{\circ} \mathrm{C}[20,22]$ and into $\alpha-\mathrm{Al}_{2} \mathrm{O}_{3}$ at $1100^{\circ} \mathrm{C}[21$, 22 . Because of the density difference between the crystalline phase and amorphous phase, the crystallization causes a shrink of film thickness [20], affecting the mechanical stability of the $\mathrm{Al}_{2} \mathrm{O}_{3}$ films. The crystallization would affect the mechanical stability of the ALD films on TEM grids above $900^{\circ} \mathrm{C}$, like shown in Figure $2(\mathrm{~d})$. Atomic force microscopy shows that the roughness of the $\mathrm{Al}_{2} \mathrm{O}_{3}$ films increases after high-temperature annealing over $1000^{\circ} \mathrm{C}[21,22]$. When the roughness of the locally crystallized films is higher than the thickness of the unannealed amorphous films, voids appear in the $\mathrm{Al}_{2} \mathrm{O}_{3}$ films because of the shrink of thickness. The mechanical stability of the $\mathrm{Al}_{2} \mathrm{O}_{3}$ films depends on the properties of the voids (size and number per volume). Therefore, the thicker films are more mechanically stable. Amorphous films with $10 \mathrm{~nm}$ thickness are mechanically stable above $1200^{\circ} \mathrm{C}$ in vacuum, while stable below $985^{\circ} \mathrm{C}$ when thickness is $2 \mathrm{~nm}$. However, the mechanical un-stability at high temperature in air (like shown in Figure 2(b) where temperature is $700^{\circ} \mathrm{C}$, below the crystallization temperature of $900^{\circ} \mathrm{C}$ ) should come from other reasons, not from the crystallization.

The thermal stability is dependent on the thickness of the ALD $\mathrm{Al}_{2} \mathrm{O}_{3}$ films. Here, we define a mechanically stable temperature $T_{s}$ at which the $\mathrm{ALD} \mathrm{Al}_{2} \mathrm{O}_{3}$ films break. Figure 3 shows the thickness dependence of $T_{s}$. TEM observation indicates that the thicker the $\mathrm{ALD} \mathrm{Al}_{2} \mathrm{O}_{3}$ films, the higher the $T_{s}$. For example, the ALD $\mathrm{Al}_{2} \mathrm{O}_{3}$ films with $10 \mathrm{~nm}$ thickness are mechanically stable up to $700^{\circ} \mathrm{C}$ in air while the films with $25 \mathrm{~nm}$ thickness are stable up to $1000^{\circ} \mathrm{C}$ in air.

In order to examine the $\mathrm{ALD} \mathrm{Al}_{2} \mathrm{O}_{3}$ amorphous films further, commercial silver nanoparticles with diameter less than $20 \mathrm{~nm}$ were deposited on a $\mathrm{ALD} \mathrm{Al}_{2} \mathrm{O}_{3}$ amorphous film and heated in situ up to $900^{\circ} \mathrm{C}$ in vacuum. Figure 4 shows an in situ HRTEM image and SAED of a silver nanoparticle taken at $500^{\circ} \mathrm{C}$ in vacuum, showing the polycrystalline nature of the silver nanoparticle. Quality of the obtained HRTEM image is almost the same as those obtained using the conventional ultra-thin carbon films with thickness of several nanometers. The diffraction halos of the ALD $\mathrm{Al}_{2} \mathrm{O}_{3}$ film are very weak and hardly seen under our experimental conditions (inset of Figure 4). 
The copper grids used to support the TEM-supporting films usually evaporate at high temperature and contaminate the TEM-supporting films [13]. Different from conventional coated copper grids, no copper contamination is observed on the $\mathrm{Al}_{2} \mathrm{O}_{3}$ films after the ALD films are heated at $1000^{\circ} \mathrm{C}$ in vacuum. One possible explanation is that the condense $\mathrm{Al}_{2} \mathrm{O}_{3}$ film deposited on the copper grids limits the high vaporization of copper. In order to avoid the potential grid contamination, especially when heated in air, other kinds of TEM grids with low vapor pressure, like molybdenum and nitride TEM grids can be employed to support the $\mathrm{Al}_{2} \mathrm{O}_{3}$ films.

When an intense electron beam with $500 \mathrm{pA} / \mathrm{cm}^{2}$ irradiates on the $\mathrm{Al}_{2} \mathrm{O}_{3}$ films, a local temperature gradient is produced. Because of low thermal conductivity of $\mathrm{Al}_{2} \mathrm{O}_{3}$, the $\mathrm{Al}_{2} \mathrm{O}_{3}$ films, especially the thin $\mathrm{Al}_{2} \mathrm{O}_{3}$ films, wrap under the irradiation. The behavior is different from the conventional carbon supporting films in which the intense electron beam usually burns a hole on the carbon films. We examined the wrapped $\mathrm{Al}_{2} \mathrm{O}_{3}$ films using SAED and HRTEM and no crystallization is observed on the irradiated $\mathrm{Al}_{2} \mathrm{O}_{3}$ films. Under our TEM experimental conditions where the beam is less than $350 \mathrm{pA} / \mathrm{cm}^{2}$, the $\mathrm{Al}_{2} \mathrm{O}_{3}$ amorphous films are mechanically stable, even at high temperatures up to $1000^{\circ} \mathrm{C}$ in vacuum, under an irradiation of the electron beam.

Compared with other TEM-supporting films, the ALD $\mathrm{Al}_{2} \mathrm{O}_{3}$ films are more suitable for HRTEM imaging of nanoparticles at high temperatures. The ALD films not only mechanically support the observed nanoparticles at high temperatures but also are thin enough for HRTEM imaging. Graphene sheets have been commercially used for TEM-supporting films and are super for atomic-resolution transmission electron microscopy because of its thickness [23]. However, the graphene sheets are not thermally stable at high-temperature, especially oxidized in air at high temperatures, limiting high temperature application. Silicon-based membranes with thickness down to $10 \mathrm{~nm}$ are commercially available and can stand over $1000^{\circ} \mathrm{C}$ in air. However, the thickness of the membranes is still too thick to obtain clear HRTEM images of nanoparticles with a diameter of several nanometers. More unfortunately, it is hard to further reduce the thickness of the silicon-based membranes because of complex etching technology. So the ALD $\mathrm{Al}_{2} \mathrm{O}_{3}$ films are super than the graphene sheets and the siliconbased membrane windows after considering the mechanical stability at high temperatures and the atomic-resolution imaging of nanoparticles. Additionally, the fabrications of the graphene sheets and the silicon-based membranes are complex and these TEM-supporting films are expensive. On the contrary, the $\mathrm{ALD} \mathrm{Al}_{2} \mathrm{O}_{3}$ films can be fabricated much easier and can be massively produced in a short time. The produced $\mathrm{Al}_{2} \mathrm{O}_{3}$ supporting films should be much cheaper than the graphene sheets and the membrane windows.

\section{Conclusions}

In summary, ultra-thin, oxidization resistant, amorphous $\mathrm{Al}_{2} \mathrm{O}_{3}$ supporting films are deposited on conventional TEM grids by atomic layer deposition. The amorphous films with $2 \mathrm{~nm}$ thickness are mechanically stable up to $600^{\circ} \mathrm{C}$ in air and over $900^{\circ} \mathrm{C}$ in vacuum, suitable for high-temperature HRTEM and high-temperature SAED. The coated TEM grids can withstand higher temperature when the thickness of $\mathrm{Al}_{2} \mathrm{O}_{3}$ supporting films increases.

\section{Acknowledgment}

The paper is supported by Defense Threat Reduction Agency under a grant HDTRA1-07-1-0015.

\section{References}

[1] R. J. Spontak, J. L. Burns, and C. J. Echer, "Morphological studies of nanoclusters on grid-supported polymer thin films," Journal of Materials Research, vol. 7, no. 9, pp. 2593-2598, 1992.

[2] C. E. Kliewer, G. Kiss, and G. J. DeMartin, "Ex situ transmission electron microscopy: a fixed-bed reactor approach," Microscopy and Microanalysis, vol. 12, no. 2, pp. 135-144, 2006.

[3] R. Kofman, P. Cheyssac, Y. Lereah, and A. Stella, "Melting of clusters approaching 0D," European Physical Journal D, vol. 9, no. 1-4, pp. 441-444, 1999.

[4] Z. L. Wang, J. M. Petroski, T. C. Green, and M. A. ElSayed, "Shape transformation and surface melting of cubic and tetrahedral platinum nanocrystals," Journal of Physical Chemistry B, vol. 102, no. 32, pp. 6145-6151, 1998.

[5] Q. Xu, I. D. Sharp, C. W. Yuan et al., "Large melting-point hysteresis of $\mathrm{Ge}$ nanocrystals embedded in $\mathrm{SiO}_{2}$," Physical Review Letters, vol. 97, no. 15, Article ID 155701, 4 pages, 2006.

[6] K. Koga, T. Ikeshoji, and K.-I. Sugawara, "Size- and temperature-dependent structural transitions in gold nanoparticles," Physical Review Letters, vol. 92, no. 11, Article ID 115507, 4 pages, 2004.

[7] K. K. Nanda, F. E. Kruis, and H. Fissan, "Evaporation of free PbN nanoparticles: evidence of the Kelvin effect," Physical Review Letters, vol. 89, no. 25, Article ID 256103, 4 pages, 2002.

[8] P. W. Sutter and E. A. Sutter, "Dispensing and surface-induced crystallization of zeptolitre liquid metal-alloy drops," Nature Materials, vol. 6, no. 5, pp. 363-366, 2007.

[9] H. Yasuda, K. Mitsuishi, and H. Mori, "Particle-size dependence of phase stability and amorphouslike phase formation in nanometer-sized Au-Sn alloy particles," Physical Review B, vol. 64, no. 9, Article ID 094101, 6 pages, 2001.

[10] H. Yasuda, A. Tanaka, K. Matsumoto, N. Nitta, and H. Mori, "Formation of porous GaSb compound nanoparticles by electronic-excitation- induced vacancy clustering," Physical Review Letters, vol. 100, no. 10, Article ID 105506, 4 pages, 2008.

[11] Y. Lan, H. Wang, X. Chen, D. Wang, G. Chen, and Z. Ren, "Nanothermometer using single crystal silver nanospheres," Advanced Materials, vol. 21, no. 47, pp. 4839-4844, 2010.

[12] R. C. Williams and R. M. Glaeser, "Ultrathin carbon support films for electron microscopy," Science, vol. 175, no. 4025, pp. 1000-1001, 1972.

[13] D. L. Jernigan and J. L. McAtee Jr., "The study of carboncoated grids at elevated temperatures by electron microscopy," Thermochimica Acta, vol. 4, no. 3-5, pp. 393-404, 1972.

[14] S. Janbroers, T. R. de Kruijff, Q. Xu, P. J. Kooyman, and H. W. Zandbergen, "Preparation of carbon-free TEM microgrids by 
metal sputtering," Ultramicroscopy, vol. 109, no. 9, pp. 11051109, 2009.

[15] B. V. Johansen and H. Ormstad, "Evaporated germanium films as supports for microanalysis of carbon and silicon containing specimens," Microscopy Research and Technique, vol. 38, no. 5, pp. 519-524, 1997.

[16] G. J. Kearns, E. W. Foster, and J. E. Hutchison, "Substrates for direct imaging of chemically functionalized $\mathrm{SiO}_{2}$ surfaces by transmission electron microscopy," Analytical Chemistry, vol. 78, no. 1, pp. 298-303, 2006.

[17] A. W. Grant, Q.-H. Hu, and B. Kasemo, "Transmission electron microscopy 'windows' for nanofabricated structures," Nanotechnology, vol. 15, no. 9, pp. 1175-1181, 2004.

[18] M. Leskelä and M. Ritala, "Atomic layer deposition chemistry: recent developments and future challenges," Angewandte Chemie International Edition, vol. 42, no. 45, pp. 5548-5554, 2003.

[19] N. P. Kobayashi, C. L. Donley, S.-Y. Wang, and R. S. Williams, "Atomic layer deposition of aluminum oxide on hydrophobic and hydrophilic surfaces," Journal of Crystal Growth, vol. 299, no. 1, pp. 218-222, 2007.

[20] S. Jakschik, U. Schroeder, T. Hecht, M. Gutsche, H. Seidl, and J. W. Bartha, "Crystallization behavior of thin ALD- $\mathrm{Al}_{2} \mathrm{O}_{3}$ films," Thin Solid Films, vol. 425, no. 1-2, pp. 216-220, 2003.

[21] L. Zhang, H. C. Jiang, C. Liu, J. W. Dong, and P. Chow, "Annealing of $\mathrm{Al}_{2} \mathrm{O}_{3}$ thin films prepared by atomic layer deposition," Journal of Physics D, vol. 40, no. 12, pp. 37073713, 2007.

[22] P. Eklund, M. Sridharan, G. Singh, and J. Bøttiger, "Thermal stability and phase transformations of $\gamma$-amorphous- $\mathrm{Al}_{2} \mathrm{O}_{3}$ thin films," Plasma Processes and Polymers, vol. 6, no. S1, pp. S907-S911, 2009.

[23] Z. Lee, K.-J. Jeon, A. Dato et al., "Direct imaging of soft-hard interfaces enabled by graphene," Nano Letters, vol. 9, no. 9, pp. 3365-3369, 2009. 

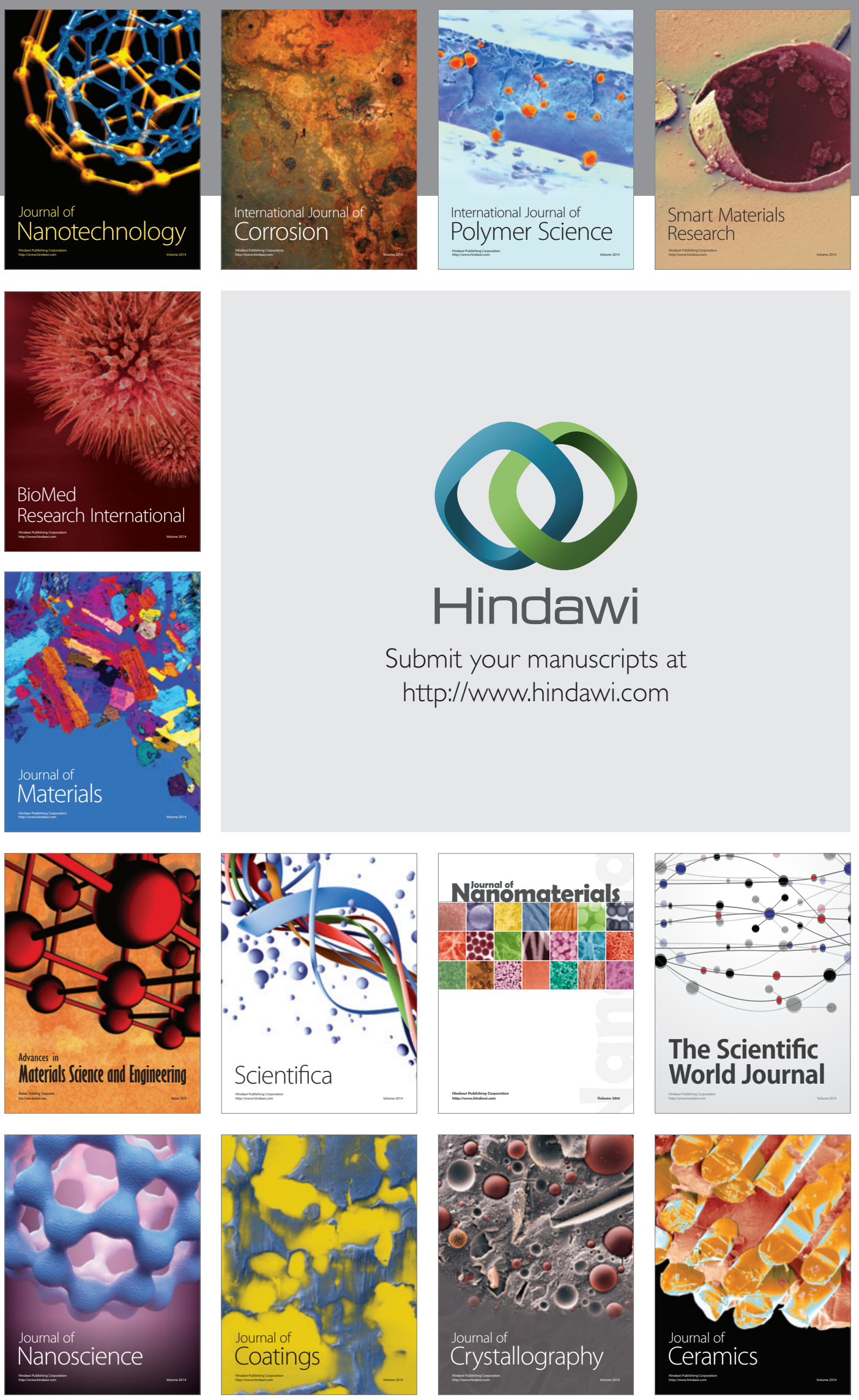

The Scientific World Journal

Submit your manuscripts at

http://www.hindawi.com

\section{World Journal}

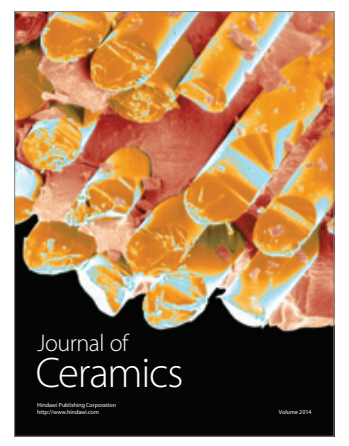

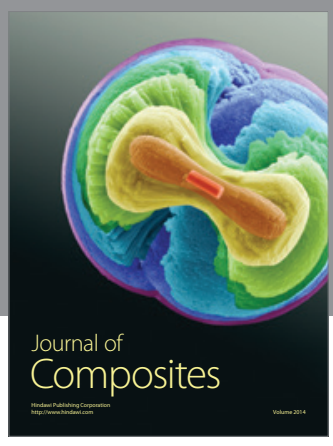
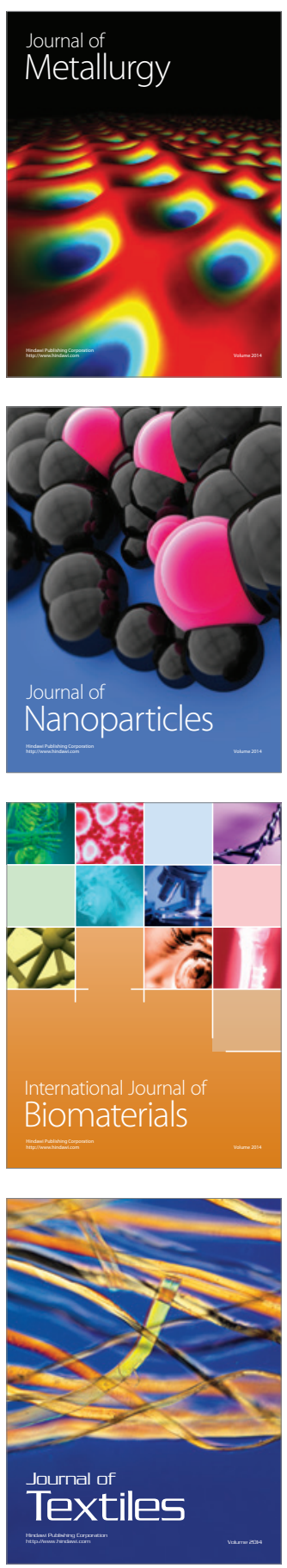